\title{
Recent occurrence of toxic Gymnodinium catenatum Graham (Gymnodiniales, Dinophyceae) in coastal sediments of West Japan
}

\author{
KAZUMI MATSUOKA ${ }^{1}$, RIKA FUJII ${ }^{2}$, MASAO HAYASHI ${ }^{3}$ AND ZHAOHUI WANG ${ }^{4}$ \\ ${ }^{1}$ Institute for East China Sea Research, Nagasaki University, 1551-7 Taira-machi, Nagasaki, 851-2213, Japan \\ (e-mail: kazu-mtk@nagasaki-u.ac.jp) \\ ${ }^{2}$ Graduate School of Science and Technology, Nagasaki University, 1-14 Bunkyo-machi, Nagasaki, 852-8521, Japan \\ ${ }^{3}$ Laboratory of Coastal Environmental Sciences, Faculty of Fisheries, Nagasaki University, 1-14 Bunkyo-machi, \\ Nagasaki, 852-8521, Japan \\ ${ }^{4}$ Institute of Hydrobiology, Jinan University, Guanzo, 510631, China
}

Received April 9, 2005; Revised manuscript accepted December 7, 2005

\begin{abstract}
In Japan, a paralytic shellfish poison (PSP) event caused by Gymnodinium catenatum Graham, a naked, colonial and PSP dinoflagellate, was first reported from Senzaki Bay, western part of the Sea of Japan in 1986. Since then, the geographical distribution of this species seems to have expanded through West Japan. To clarify the possibility of its migration being due to anthropogenic agency the historical occurrence of $G$. catenatum in Japanese coastal waters was examined; core sediments that preserve an historical record of this species were collected from several coastal areas where it had been observed. From the cores collected from Imari Bay, smaller spherical cysts ornamented with fine reticulated structure and with epicystal archeopyle are found which are probably different from Gymnodinium nolleri. Low cyst concentrations of $G$. catenatum in these cores may have resulted from such a characteristic physiological feature as chain formation of its vegetative form. The earliest occurrence of this species was recorded in sediment of Omura Bay dated to ca. 1700 A.D. This fact strongly suggests that the occurrence of $G$. catenatum in Japan is natural and that it has not been artificially introduced from different areas.
\end{abstract}

Key words: Gymnodinium catenatum, PSP, dinoflagellate cyst, harmful algae, recent sediment

\section{Introduction}

For understanding the expansion mechanism of harmful marine micro-algae, occurrence histories of these organisms are important and useful. Under this concept, several stratigraphical studies on harmful species have been conducted so far (e.g., Furio et al., 1996; McMinn et al., 1997, 2001). Mainly two different theories concerning the expansion of harmful species have been presented. According to Furio et al. (1996) the intensive blooms of Pyrodinium bahamense var. compressum since the late 1980's, in Manila Bay, Philippines, are probably due to oceanographic environmental changes. This is based on the fact that only a few resting cysts of $P$. bahamense var. compressum were recovered from sediments dated to around 1958. On the other hand, McMinn et al. (1997) concluded that since the cysts of Gymnodinium catenatum Graham from Tasmania, Australia, were first detected in sediments from around 1975, which is just before this species started producing intensive blooms, Tasmanian G. catenatum might have been artificially introduced from other areas.

Gymnodinium catenatum, a naked, colonial dinoflagellate, is known to be a causative species of PSP (paralytic shellfish poison). Toxic events derived from this species were first reported in Spain in 1976, and then expanded worldwide (Hallegraeff, 1993). Thereafter, the geographical occurrence of $G$. catenatum has increased, mainly in subtropical to tropical coastal waters (Viquez and Hargraves, 1995; Hodgkiss and Yang, 2001). In particular, Tasmania, Australia was first affected by PSP from this species in 1986. At that time, since this species had never been described from Australian coastal waters, Hallegraeff (1992) suggested that it might be introduced in Tasmania from other regions by ballast waters.

In Japan, a PSP event caused by G. catenatum was 
first reported from Senzaki Bay in the western part of Japan (Ikeda et al., 1989). Since then, the geographical distribution of this species seems to have expanded throughout West Japan (Matsuoka and Fukuyo, 1994; Red Tide Division in Nansei National Fisheries Research Institute, 1998). Simultaneously, PSP events related to this species have also increased in West Japan. However, Matsuoka and Fukuyo (1994) mentioned that this species was reported but not described from Omura Bay, West Kyushu under the name Gymnodinium $\mathrm{A}_{5}$ by Iizuka in 1968 .

The purpose of this study is to clarify the historical occurrence of $G$. catenatum in Japanese coastal waters based on the fossil evidence recorded in recent sediments and to seek its possible migration mechanism.

\section{Material and methods}

In total, 11 sediment cores were collected from Omura Bay, Nagasaki Bay, Imari Bay and Ariake Sound in West Kyushu, Hiroshima Bay in the Seto Inland Sea, and Matoya Bay in Ise Bay, Central Japan, where vegetative cells and resting cysts of Gymnodinium catenatum have been known to occur (Figures 1, 2; Matsuoka and Fukuyo, 1994). The core samples from Omura Bay, Nagasaki Bay and Ariake Sound were collected by divers, and the samples from Imari Bay, Hiroshima Bay and Matoya Bay were taken with a handy piston corer developed by Nanba et al. (1998). These core samples were sliced every $1 \mathrm{~cm}$ or $2 \mathrm{~cm}$ and kept in a refrigerator.

Extraction of dinoflagellate cysts from the samples followed the methods of Matsuoka and Fukuyo

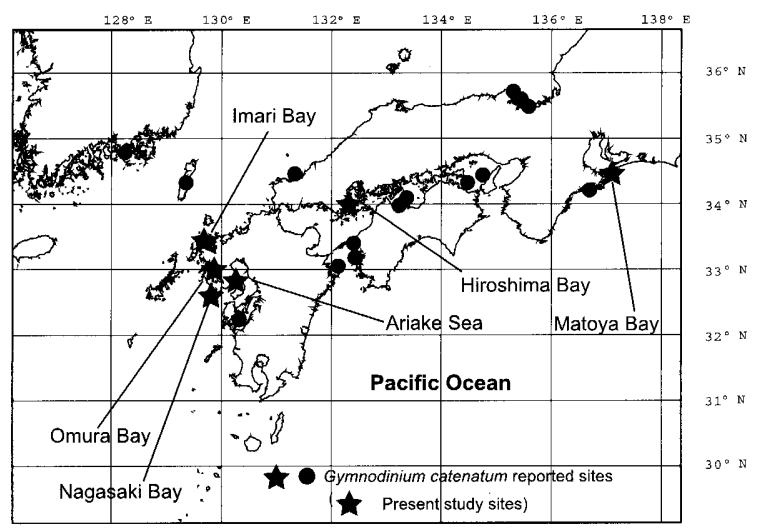

Figure 1. Map showing the reported occurrences of Gymnodinium catenatum (vegetative cells and cysts) (Matsuoka and Fukuyo, 1994; Red Tide Division of Nansei National Fisheries Research Institute, 1998) and the sampling locations in West Japan of the present study.

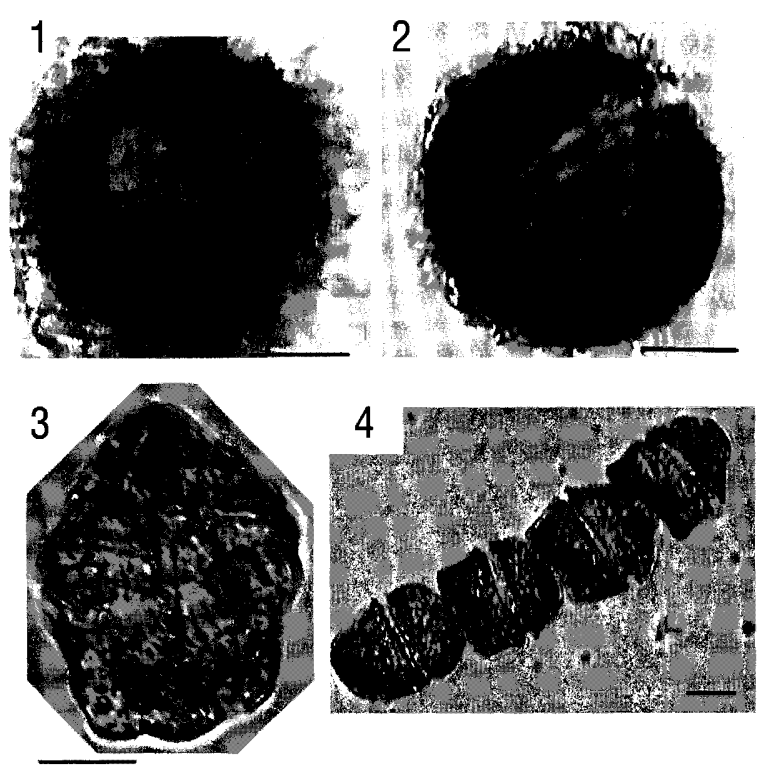

Figure 2. Morphology of Gymnodinium catenatum in different life stages. 1. Living cyst filled with fresh protoplasm occurring in surface sediment. 2. Empty cyst after germination during laboratory incubation experiment showing a large chasmic archeopyle. 3. Planktonic cell germinated from the cyst (1). 4 . Vegetative stage making a chain composed of four cells, in a week after germination. These cells were originally the single cyst collected from Imari Bay. (scale bars: $15 \mu \mathrm{m}$ )

(2000). Approximately $2 \mathrm{~g}$ of each sample were placed into an acid-resistant $100 \mathrm{ml}$ beaker. To remove calcium carbonate, ca. $10 \%$ diluted hydrochloric acid was added, and to dissolve silicate substances ca. 35\% hydrofluoric acid was used. After rinsing the samples with pure water, they were sieved through two stainless steel screens of $120 \mu \mathrm{m}$ and $20 \mu \mathrm{m}$ opening size. The concentrated residue on the $20 \mu \mathrm{m}$ screen was suspended in $10 \mathrm{ml}$ distilled water and kept in a vial. A $1-0.5 \mathrm{ml}$ aliquot of the refined samples was provided for observation under an inverted microscope (Olympus IX70). All cysts encountered during scanning of the samples were identified and counted. For calculating the relative frequency of the cysts of $G$. catenatum, cyst concentration in each sample was initially taken as cysts per wet sediment volume, and was subsequently calculated to give final concentrations in cysts/g dry weight sediment. The data of $G$. catenatum cyst concerntrations in samples of Omura Bay and Nagasaki Bay were originally provided by Kim and Matsuoka (1998) and Matsuoka and Kim (1999) respectively. In these reports, the cyst concentration of each species was represented in wet sediment volume, however, there is no difference between the relative abundance of $G$. catenatum cysts measured in cysts per 
gram dry sediment and those measured in cysts per wet sediment volume.

\section{Age assignment of core sediments}

For estimating depositional ages of the core sediments, sedimentation rates of these core samples in average were measured by ${ }^{210} \mathrm{~Pb}$ concentration (e.g., Jeter, 2000). Technical support for ${ }^{210} \mathrm{~Pb}$ measurement in each of the core samples was provided by Teledyne Isotope Co. LTD. After establishing sedimentation rates for the core samples, the depositional ages for the analyzed samples were estimated.

\section{Results}

\section{Sedimentation rates of core samples (Table 1)}

From Omura Bay, two core samples were provided for the study; OMB-1 (sampling site: $32^{\circ} 54^{\prime} \mathrm{N}$, $129^{\circ} 50^{\prime} \mathrm{E}$, water depth $21 \mathrm{~m}$ ), the core is $99 \mathrm{~cm}$ long, consisting of olive grey homogeneous silt with very small shell fragments and the sedimentation rate is $2.7 \mathrm{~mm} /$ year, and OMB-2 (sampling site: $32^{\circ} 50^{\prime} \mathrm{N}$, $129^{\circ} 58^{\prime} \mathrm{E}$, water depth $9 \mathrm{~m}$ ), the core is $76 \mathrm{~cm}$ in length, consisting of homogeneous olive grey silt with shell fragments, and the sedimentation rate is $2.1 \mathrm{~mm} /$ year. $5 \mathrm{~cm}$ interval samples of these cores were provided for analysis. From the upper $10 \mathrm{~cm}$ of sediment, every $1 \mathrm{~cm}$ interval was analyzed.

Table 1. List of sedimentation rates of core samples provided for this study and the oldest occurrence of Gymnodinium catenatum cyst in each core. Each sedimentation rate was estimated by measurements of ${ }^{210} \mathrm{~Pb}$.

\begin{tabular}{|c|c|c|c|c|}
\hline Location & $\begin{array}{c}\text { Station } \\
\text { No. }\end{array}$ & $\begin{array}{l}\text { Sedimen- } \\
\text { tation } \\
\text { rate } \\
\text { (mm/year) }\end{array}$ & $\begin{array}{c}\text { Oldest } \\
\text { occurrence of } \\
\text { Gymnodinium } \\
\text { catenatum } \\
\text { Sample } \\
\text { depth } \\
(\mathrm{cm})\end{array}$ & $\begin{array}{l}\text { Age } \\
\text { (A.D.) }\end{array}$ \\
\hline Omura Bay & $\begin{array}{l}\text { OMB-1 } \\
\text { OMB-2 }\end{array}$ & $\begin{array}{l}2.7 \\
2.1\end{array}$ & $\begin{array}{l}90-91 \\
55-56\end{array}$ & $\begin{array}{l}\text { ca. } 1660 \\
\text { ca. } 1730\end{array}$ \\
\hline Nagasaki Bay & $\begin{array}{l}\text { NGB-1 } \\
\text { NGB-2 }\end{array}$ & $\begin{array}{l}9.9 \\
4.3\end{array}$ & $\begin{array}{l}70-71 \\
55-56\end{array}$ & $\begin{array}{l}\text { ca. } 1920 \\
\text { ca. } 1850\end{array}$ \\
\hline Imari Bay & $\begin{array}{l}\text { IMB-1 } \\
\text { IMB-2 }\end{array}$ & $\begin{array}{l}3.2 \\
2.4\end{array}$ & $\begin{array}{l}60-61 \\
50-51\end{array}$ & $\begin{array}{l}\text { ca. } 1810 \\
\text { ca. } 1780\end{array}$ \\
\hline Ariake Sound & ARK-3 & 5.8 & $18-19$ & ca. 1970 \\
\hline $\begin{array}{l}\text { Hiroshima } \\
\text { Bay }\end{array}$ & $\begin{array}{l}\text { HRB-1 } \\
\text { HRB-3 }\end{array}$ & $\begin{array}{l}9.3 \\
3.6\end{array}$ & $\begin{array}{l}79-80 \\
44-45\end{array}$ & $\begin{array}{l}\text { ca. } 1870 \\
\text { ca. } 1920\end{array}$ \\
\hline Matoya Bay & $\begin{array}{l}\text { МTB-1 } \\
\text { МTB-2 }\end{array}$ & $\begin{array}{l}5.5 \\
4.1\end{array}$ & $\begin{array}{l}30-31 \\
68-69\end{array}$ & $\begin{array}{l}\text { ca. } 1940 \\
\text { ca. } 1830\end{array}$ \\
\hline
\end{tabular}

From Nagasaki Bay, two core samples were used for the study; NGB-1 (sampling site: $32^{\circ} 41^{\prime} \mathrm{N}, 129^{\circ} 49^{\prime} \mathrm{E}$, water depth $26.3 \mathrm{~m}$ ), the core is $86 \mathrm{~cm}$ in length, consisting of homogeneous greenish olive sandy silt to greenish grey silty sand with shell fragments, and the sedimentation rate is $9.9 \mathrm{~mm} /$ year, and NGB-2 (sampling site: $32^{\circ} 40^{\prime} \mathrm{N}, 129^{\circ} 48^{\prime} \mathrm{E}$, water depth $25 \mathrm{~m}$ ), the core is $60 \mathrm{~cm}$ long, consisting of homogeneous grayish olive sandy silt in the upper $40 \mathrm{~cm}$ and greenish grey silty sand with many shell fragments in the lower part, and the sedimentation rate is $4.3 \mathrm{~mm} /$ year. $5 \mathrm{~cm}$ interval samples were used for analysis.

From Imari Bay, two core samples were prepared for the study; IMB-1 (sampling site: $33^{\circ} 21^{\prime} \mathrm{N}$, $129^{\circ} 45^{\prime} \mathrm{E}$, water depth $32.1 \mathrm{~m}$ ), the core is $61 \mathrm{~cm}$ long, comprising homogeneous greenish grey silt with small shell fragments, and the sedimentation rate is $3.2 \mathrm{~mm} /$ year, and IMB-2 (sampling site: $33^{\circ} 19^{\prime} \mathrm{N}$, $129^{\circ} 50^{\prime} \mathrm{E}$, water depth $5 \mathrm{~m}$ ), the core is $51 \mathrm{~cm}$ in length, comprising homogeneous greenish grey to dark grey silt, and the sedimentation rate is $2.4 \mathrm{~mm} /$ year. $5 \mathrm{~cm}$ interval samples were provided for analysis. From the upper $10 \mathrm{~cm}$ of sediment, $1 \mathrm{~cm}$ interval samples were analyzed.

From Ariake Sound, one core sample was used for the study, ARK-3 (sampling site: $33^{\circ} 21^{\prime} \mathrm{N}, 129^{\circ} 45^{\prime} \mathrm{E}$, water depth $3 \mathrm{~m}$ ), the core is $100 \mathrm{~cm}$ long, consisting of homogeneous dark olive grey silt with small shell fragments, and the sedimentation rate is $5.8 \mathrm{~mm} / \mathrm{year}$. $5 \mathrm{~cm}$ interval samples were provided for analysis. From the upper $10 \mathrm{~cm}$ of sediment, samples were analyzed every $1 \mathrm{~cm}$.

From Hiroshima Bay, two core samples were prepared for the study; HRB-1 (sampling site: $34^{\circ} 13.8^{\prime} \mathrm{N}, 132^{\circ} 31.6^{\prime} \mathrm{E}$, water depth $19.7 \mathrm{~m}$ ), the core is $81.5 \mathrm{~cm}$ long, comprising homogeneous lightly brownish grey sandy silt with shell fragments concentrated around $20 \mathrm{~cm}$ depth, and the sedimentation rate is $9.3 \mathrm{~mm} /$ year, and HRB-3 (sampling site: $34^{\circ} 14.3^{\prime} \mathrm{N}, 132^{\circ} 27.4^{\prime} \mathrm{E}$, water depth $24.3 \mathrm{~m}$ ), the core is $63 \mathrm{~cm}$ in length, comprising homogeneous greenish dark grey silt at the upper part with small shell fragments and semi-hard grey silt at the lower part, and the sedimentation rate is $3.6 \mathrm{~mm} /$ year. $5 \mathrm{~cm}$ interval samples were provided for analysis. From the upper $10 \mathrm{~cm}$ of sediment, samples were analyzed every $1 \mathrm{~cm}$.

From Matoya Bay, two core samples were prepared for the study; MTB-1 $\left(34^{\circ} 40^{\prime} \mathrm{N}, 136^{\circ} 52^{\prime} \mathrm{E}\right.$, water depth $13 \mathrm{~m}$ ), the core is $59 \mathrm{~cm}$ long, consisting of olive grey sandy silt to silt with small shell fragments in the upper $20 \mathrm{~cm}$ and of homogeneous grey silt in the lower part, and the sedimentation rate is $5.5 \mathrm{~mm} /$ year, and MTB-2 (sampling site: $34^{\circ} 50^{\prime} \mathrm{N}, 136^{\circ} 53^{\prime} \mathrm{E}$, 

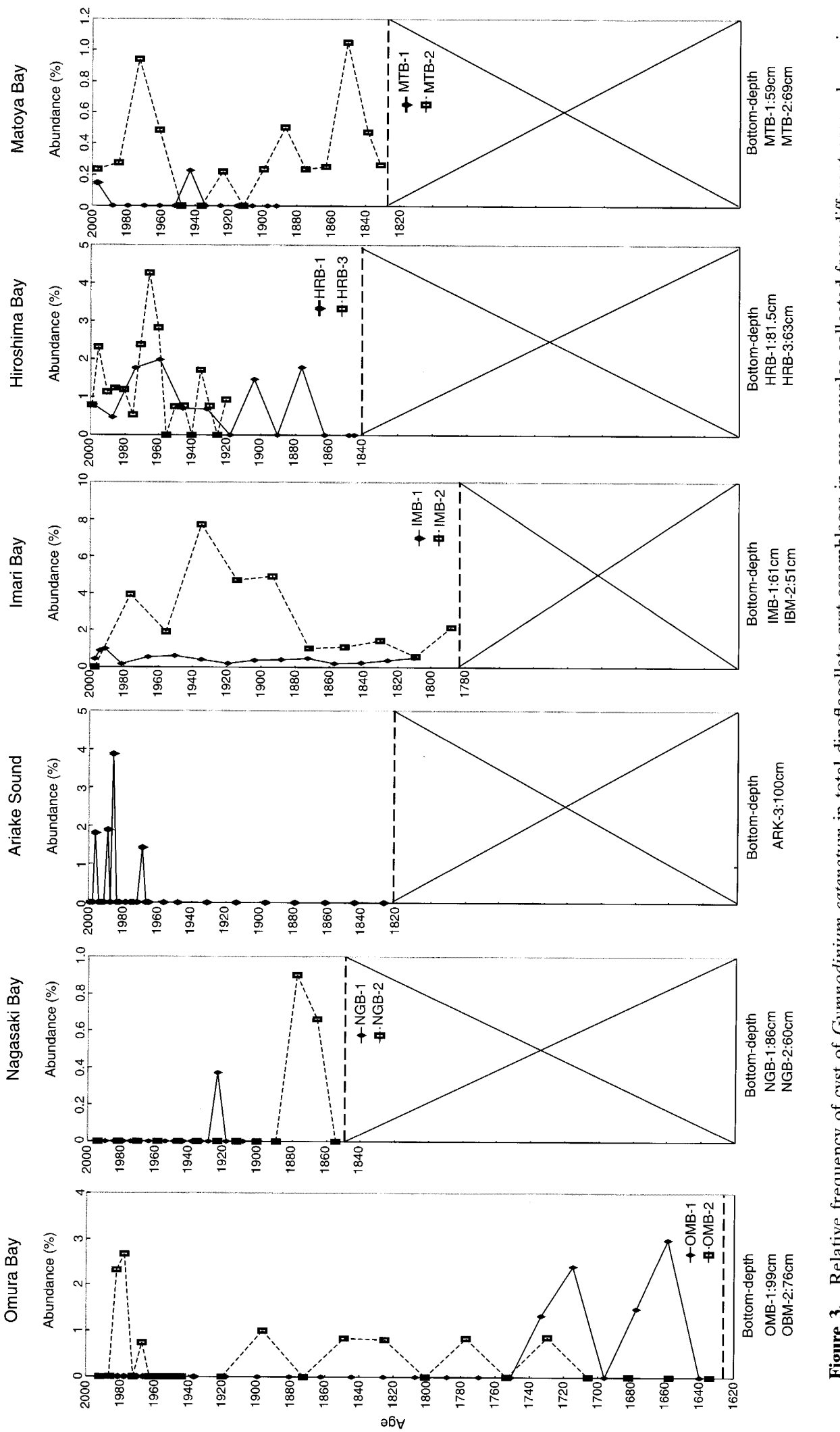
water depth $11 \mathrm{~m}$ ), the core is $69 \mathrm{~cm}$ in length, consisting of homogeneous dark grey silt with shell fragments, and the sedimentation rate is $4.1 \mathrm{~mm} / \mathrm{year}$. $5 \mathrm{~cm}$ interval samples were provided for analysis. From the upper $10 \mathrm{~cm}$ of sediment, samples were analyzed every $1 \mathrm{~cm}$.

\section{Occurrence of $\boldsymbol{G}$. catenatum cysts in core sediments (Figure 3, Table 2)}

In Omura Bay, based on the sedimentation rates, $2.7 \mathrm{~mm} /$ year at OMB-1 and $2.1 \mathrm{~mm} /$ year at OMB-2, the depositional age of the lowest part in both cores is approximately 350 years before 1994 A.D. In the core taken at OMB-1, cysts of $G$. catenatum occurred at $70-71 \mathrm{~cm}, 75-76 \mathrm{~cm}, 85-86 \mathrm{~cm}$ and $90-91 \mathrm{~cm}$ depths. In the core taken at OMB-2, G. catenatum cysts were observed at $55-56 \mathrm{~cm}$ and then continuously upward with low abundance $(1-3 \%$ in total dinoflagellate cysts).

In Nagasaki Bay, according to a sedimentation rate of $9.9 \mathrm{~mm} /$ year at NGB-1, and $4.3 \mathrm{~mm} /$ year at NGB-2, the depositional ages of the base of the cores are ca. 90 years and ca. 140 years before 1995 A.D., respectively. In both cores, $G$. catenatum cysts occurred in very low frequency, mostly less than $1 \%$, and the earliest occurrence was dated back to ca. 120 year at NGB-2. However, in the middle to upper part of the cores, G. catenatum cysts were not observed.

In Imari Bay, a sedimentation rate of $3.2 \mathrm{~mm} / \mathrm{year}$ at IMB-1 and of $2.4 \mathrm{~mm} / \mathrm{year}$ at IMB-2 evidenced that the lowest part of the core is approximately 190 years old at IMB-1 and approximately 210 years old at IMB2 . In the core taken at IMB-2, the relative frequency of $G$. catenatum cysts is highest (ca. $8 \%$ of total dinoflagellate cysts) in three depth ranges. In the core taken at IMB-1, the relative frequency of $G$. catenatum is very low, less than $2 \%$, but cysts occurred continuously to the upper part of the core. The earliest record is dated back ca. 210 years.

In Ariake Sound, since the sedimentation rate for ARK-3 is $5.8 \mathrm{~mm} /$ year, the age of the earliest occurrence of cysts is approximately 30 years before the present time. In the core of ARK-3, the relative frequency of $G$. catenatum cysts is highest (ca. $3.8 \%$ in total dinoflagellate cysts) in the core and usually less than $2 \%$.

In Hiroshima Bay, based on a sedimentation rate of $3.6 \mathrm{~mm} /$ year for HRB-1, the age of the lowest part of the core is approximately 125 years before. In the core taken at HRB-1, the relative frequency of $G$. catenatum cysts is high (ca. $2 \%$ of total dinoflagellate cysts) and usually less than $1 \%$.

In Matoya Bay, according to the sedimentation rates of $5.5 \mathrm{~mm} /$ year at MTB-1 and $4.1 \mathrm{~mm} /$ year at MTB-2, the earliest occurrence of $G$. catenatum was recorded at ca. 1840 A.D. and 1855 A.D., respectively.

In summary, the relative frequency of $G$. catenatum cysts in analyzed samples is always very low, less than $8 \%$ even in the case of the highest abundance, in comparison with other cysts of autotrophic species, such as Spiniferites bulloideus and Protoceratium reticulatum.

\section{Discussion}

\section{Cyst morphology of Gymnodinium catenatum}

After the first report of the cyst of $G$. catenatum by Anderson et al. (1988), two morphologically similar cysts were found; non-toxic Gymnodinium nolleri (Ellegard and Moestrup, 1999) (Figure 4) and non-toxic Gymnodinium microreticulatum (Bolch et al., 1999). Ellegard and Moestrup (1999) pointed out that fossilized cysts previously identified as $G$. catenatum in sediments from the North Sea by Dale et al. (1993) were not the cyst of $G$. catenatum but rather $G$. nolleri, because there was no record of vegetative cells of $G$. catenatum so far in the area. These three cysts, with fine reticulation on the surface, have a brownish cyst wall and only differ from each other in their cyst diameters. Bolch et al. (1999) clarified that the cyst of $G$. microreticulatum is the smallest, approximately $30 \mu \mathrm{m}$ in diameter, the cyst of $G$. catenatum is the largest, approximately $50 \mu \mathrm{m}$ in diameter, and the cyst of $G$. nolleri is intermediate, approximately $40 \mu \mathrm{m}$ in diameter, although diameters of these cysts overlapped each other. Additionally, G. microreticulatum has a different, transsulcal archeopyle from the latter two, which have an epicystal archeopyle. More recently Bolch and Raynolds (2002) reexamined the morphology of microreticulate dinoflagellate cysts collected from various sites from Australia, the Black Sea, Italy, Hong Kong and Uruguay, and showed different cyst diameters for these three species; G. catenatum $(36-62 \mu \mathrm{m})$, G. nolleri $(25-40 \mu \mathrm{m})$, and $G$. microreticulatum (17$29 \mu \mathrm{m})$.

In sediments of Imari Bay, fine reticulate cysts with different diameters [40-60 $\mu \mathrm{m}$ (Figure 4-1) and 20$30 \mu \mathrm{m}$ (Figure 4-2)] were observed. The smaller cysts have diameters in the range of $G$. nolleri, but the vegetative cell of $G$. nolleri has never been observed in plankton samples in the bay. Furthermore, the environmental conditions, in particular water temperature, between Imari Bay and the North Sea are different, more than $25^{\circ} \mathrm{C}$ in Imari Bay and less than $20^{\circ} \mathrm{C}$ in the North Sea in summer. These smaller cysts are not identical with $G$. nolleri, and probably belong to a different species. An undescribed dinoflagellate whose 
Table 2. Relative frequency of Gymnodinium catenatum cyst in total dinoflagellate assemblages.

\begin{tabular}{|c|c|c|c|c|c|c|c|c|c|c|c|c|}
\hline Omura-1 (\%)/Depth $(\mathrm{cm})$ & $0-1$ & $2-3$ & $3-4$ & $4-5$ & $5-6$ & $6-7$ & $7-8$ & $8-9$ & $9-10$ & $10-11$ & $15-16$ & $20-21$ \\
\hline Gonyaulacoid & 4455 & 31.28 & 32.39 & 26.55 & 39.44 & 38.70 & 32.42 & 30.26 & 25.45 & 34.62 & 43.72 & 58.43 \\
\hline Gymnodinioid & & & & & & & & & & & & \\
\hline Protoperidinioid & 34.65 & 43.13 & 38.97 & 45.13 & 28.57 & 40.43 & 48.86 & 45.64 & 46.88 & 37.18 & 38.53 & 24.72 \\
\hline total & 100.00 & 100.00 & 100.00 & 100.00 & 100.00 & 100.00 & 100.00 & 100.00 & 100.00 & 100.00 & 100.00 & 100.00 \\
\hline Gymnodinium c & 0.00 & 0.00 & 0.00 & 0.00 & 0.00 & 0.00 & 0.00 & 0.00 & 0.00 & 0.00 & 0.00 & 0.00 \\
\hline Omura-2 (\%)/Depth $(\mathrm{cm})$ & $0-1$ & $1-2$ & $2-3$ & $3-4$ & $4-5$ & $5-6$ & $6-7$ & $7-8$ & $8-9$ & $9-10$ & $10-11$ & $15-16$ \\
\hline Gonya & 30.71 & 9.86 & 16.28 & 2 & 21. & 3 & 3. & 37 & 40 & 45 & 52 & 64.46 \\
\hline $\mathrm{O}$ & & & & & & & & & & & & 6.61 \\
\hline idinioid & 48.03 & 61.70 & 68.60 & 57.33 & 61.22 & 48.51 & & & 43.31 & & & 28.93 \\
\hline total & 100.00 & 100.00 & 100.00 & 100.00 & 100.00 & 100.00 & 100.00 & 100.00 & 100.00 & 100.00 & 100.00 & 100.00 \\
\hline Gymnodinium & 0.00 & 0.00 & 2.33 & 2.67 & 0.00 & 0.75 & 0.00 & 0.00 & 0.00 & 0.00 & 0.00 & 0.00 \\
\hline Nagasaki-1 (\%)/D & $0-1$ & $5-6$ & $10-11$ & $15-16$ & $20-21$ & $25-26$ & $30-31$ & $35-36$ & $40-41$ & $45-46$ & $50-51$ & $55-56$ \\
\hline Gon & & 10 & 38.68 & 0 & 5 & 43. & 56.8 & 66.53 & 69.39 & 65.9 & 69.00 & 70.24 \\
\hline $\mathrm{G}$ & & & 34.91 & & & & & & 4.76 & & & 7.14 \\
\hline toperidinioid & & 36.84 & 26.42 & & 27.03 & 47.48 & & & 25.85 & & & 22.62 \\
\hline total & 100.00 & 100.00 & 100.00 & 100.00 & 100.00 & 100.00 & 100.00 & 100.00 & 100.00 & 100.00 & 100.00 & 100.00 \\
\hline Gymnodinium catenatum & 0.00 & 0.00 & 0.00 & 0.00 & 0.00 & 0.00 & 0.00 & 0.00 & 0.00 & 0.00 & 0.00 & 0.00 \\
\hline Nagasaki-2 (\% & $0-1$ & $5-6$ & $10-11$ & $14-15$ & $20-21$ & $25-26$ & $31-32$ & $35-36$ & $40-41$ & $44-45$ & $50-51$ & $55-56$ \\
\hline Gonya & 387 & 25.78 & 41.06 & 37.93 & 29.5 & 41 & 41.57 & 47.06 & 53.57 & 62 & 67 & 58.94 \\
\hline & & 29.69 & 19 & 6 & & & & 9 & 1.79 & & & 11.26 \\
\hline Protoperidinioid & 43.88 & 44.53 & 39.74 & & 66.39 & 49.26 & 56.18 & 43.14 & 44.64 & & & 29.80 \\
\hline total & 100.00 & 100.00 & 100.00 & 100.00 & 100.00 & 100.00 & 100.00 & 100.00 & 100.00 & 100 & & 100.00 \\
\hline Gymnodinium catenatum & 0.00 & 0.00 & 0.00 & 0.00 & 0.00 & 0.00 & 0.00 & 0.00 & 0.00 & 0.00 & 0.90 & 0.66 \\
\hline Matoya-1 (\%)/Depth (c1 & $0-1$ & $5-6$ & $10-11$ & $15-16$ & $20-21$ & $25-26$ & $30-31$ & $35-36$ & $40-41$ & $45-46$ & $50-51$ & $55-56$ \\
\hline $\mathrm{G}$ & 6 & 66.5 & 62.9 & 72.25 & 63. & 57 & 6. & 7 & 75 & 6 & 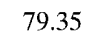 & 72.92 \\
\hline $\mathrm{C}$ & & & 4.39 & 8 & 8.34 & & & & & & & 2.11 \\
\hline Protoperidinioid & 29.52 & 30.52 & 32.63 & 25.77 & 28.30 & 37 & 32.33 & 24.81 & 22.75 & & & 24.98 \\
\hline total & 100.00 & 100.00 & 100.00 & 100.00 & 100.00 & & 100.00 & 100.00 & 100.00 & & 100.00 & 100.00 \\
\hline Gymnodinium catenatum & 0.15 & 0.00 & 0.00 & 0.00 & 0.00 & 0.00 & 0.23 & 0.00 & 0.00 & 0.00 & 0.00 & 0.00 \\
\hline Matoya-2 (\%)/Depth (cr & $0-1$ & $5-6$ & $10-11$ & $15-16$ & $20-21$ & $25-26$ & $30-31$ & $35-36$ & $40-41$ & $45-46$ & $50-51$ & $55-56$ \\
\hline $\mathrm{G}$ & & & & & 1 & & & & & & & 27 \\
\hline & & & & & & & & & & & & 1.99 \\
\hline Protoperidinioid & 40.01 & 26.83 & 41.15 & 25.23 & 26.28 & 28.71 & & & 20.34 & & & 25.74 \\
\hline total & 100.00 & 100.00 & 100.00 & 100.00 & 100.00 & & & 100 & 100.00 & & 100.00 & 100.00 \\
\hline Gymnodinium catenatum & 0.23 & 0.28 & 0.94 & 0.48 & 0.00 & 0.00 & 0.22 & 0.00 & 0.24 & 0.50 & 0.23 & 0.25 \\
\hline Imari-1 $(\%) /$ Depth $(\mathrm{cm})$ & $0-1$ & $1-2$ & $2-3$ & $5-6$ & $10-11$ & $15-16$ & $20-21$ & $25-26$ & $30-31$ & $35-36$ & $40-41$ & $45-46$ \\
\hline & & 80 & 61.17 & & 62.18 & & 63 & 64 & 64.66 & 63 & 60.30 & 93 \\
\hline 0 & & & & & 2 & & & 1 & 76 & & & 1.97 \\
\hline loid & 46.73 & 44.23 & 34.39 & 37.56 & 35.40 & 35.97 & 33.66 & 33.71 & 33.58 & & 35 & 33.09 \\
\hline & 100.00 & 100.00 & 100.00 & & & & & & 100.00 & & & 100.00 \\
\hline Gymnodinium catenatum & 0.44 & 0.89 & 0.98 & 0.18 & 0.56 & 0.61 & 0.41 & 0.22 & 0.39 & 0.42 & 0.49 & 0.20 \\
\hline Imari-2 $(\%) /$ Depth $(\mathrm{cm})$ & $0-1$ & $5-6$ & $10-11$ & $15-16$ & $20-21$ & $25-26$ & $30-31$ & $35-36$ & $40-41$ & $4 J-40$ & $50-51$ & \\
\hline & 31.37 & 1680 & 1571 & 48 & 35 & & 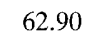 & 6 & 63.13 & 7 & 5 & \\
\hline & & & 6 & & & & & & & & & \\
\hline operidinioid & 59.22 & 90 & 52 & 68 & 31 & & 30 & 30.40 & 63 & 55 & 30.25 & \\
\hline & 100.00 & 100.00 & 100.00 & 100 & 100.00 & & 100 & 100.00 & 10 & 100 & 100.00 & \\
\hline Gymnodinium catenatum & 0.00 & 3.94 & 1.90 & 7.72 & 4.71 & 4.91 & .02 & 1.09 & 1.43 & 0.59 & 2.15 & \\
\hline Hiroshima-1 (\%)/Depth $(\mathrm{cm})$ & $0-1$ & $4-5$ & $9-10$ & $14-15$ & $19-20$ & $24-25$ & $29-30$ & $34-35$ & $39-40$ & $44-45$ & $49-50$ & $54-55$ \\
\hline & & 2. & 25 & & $T$ & & & & & & & 20.45 \\
\hline & & & 4.89 & & & & & & & & & 9.86 \\
\hline Protoperidinioid & 59.37 & 56.48 & 65.41 & 66.67 & 62.87 & 64.74 & 75.47 & 2 & 68.07 & 20 & & 69.69 \\
\hline & 100.00 & 100.00 & 100.00 & 100.00 & 100.00 & 10 & 100.00 & 100.00 & & 100.00 & 100.00 & 100.00 \\
\hline Gymno & 0.78 & 2.32 & 1.13 & 1.24 & 1.19 & 0.53 & 2.37 & 4.26 & 2.83 & 0.00 & 0.75 & 0.76 \\
\hline Hiroshima-3 (\%)/Depth $(\mathrm{cm})$ & $0-1$ & $4-5$ & $9-10$ & $14-15$ & $19-20$ & $24-25$ & $29-30$ & $34-35$ & $39-40$ & $44-45$ & $49-50$ & $54-55$ \\
\hline & & & & & & & & & & & & 50.63 \\
\hline & & & & & & & & & & & & 9.26 \\
\hline Protoperidinioid & 64.57 & 48.82 & 64.91 & 50.33 & 43.52 & & 41.14 & 50.35 & 45.09 & 47.33 & 44.61 & 40.11 \\
\hline & 100.00 & 100.00 & 100.00 & 100.00 & 100.00 & 100.00 & 100.00 & 100.00 & 100.00 & 100.00 & 100.00 & 100.00 \\
\hline Gymnodinium & 0.79 & 0.46 & 1.76 & 1.98 & 0.70 & 0.68 & 0.00 & 1.46 & 0.00 & 1.78 & 0.00 & 0.00 \\
\hline Ariake Sea-3 (\%)/Depth ( & $0-1$ & $1-2$ & $2-3$ & $3-4$ & $4-5$ & $5-6$ & $6-7$ & $7-8$ & $8-$ & $9-10$ & $10-11$ & $12-13$ \\
\hline & & & 2 & 2 & 14 & 28 & 27 & 32 & 33 & & 29.13 & 33.83 \\
\hline & & & & & & & & & & & 0.00 & 3.01 \\
\hline Protoperidinioid & 67.12 & 70.21 & 64.55 & 67.50 & 82.43 & 67.39 & 69.52 & 63.93 & 59.22 & 69.57 & 70.87 & 63.16 \\
\hline & 100.00 & 100.00 & 100.00 & 100.00 & 100.00 & 100.00 & 100.00 & 100.00 & 100.00 & 100.00 & 100.00 & 100.00 \\
\hline Gymnodinium catenatum & 0.00 & 0.00 & 1.82 & 0.00 & 0.00 & 0.00 & 1.90 & 0.00 & 3.88 & 0.00 & 0.00 & 0.00 \\
\hline
\end{tabular}




\begin{tabular}{|c|c|c|c|c|c|c|c|c|c|c|c|c|c|c|}
\hline $25-26$ & $30-31$ & $35-36$ & $40-41$ & $45-46$ & $50-51$ & $55-56$ & $60-61$ & $65-66$ & $70-71$ & $75-76$ & $80-81$ & $85-86$ & $90-91$ & $95-96$ \\
\hline 79.85 & 82.09 & 74.39 & 77.40 & 66.43 & 74.00 & 86.64 & 72.96 & 64.10 & 59.73 & 65.06 & 66.33 & 63.05 & 52.34 & 66.98 \\
\hline 6.72 & 5.22 & 11.59 & 10.96 & 15.00 & 6.00 & 6.11 & 11.16 & 13.33 & 12.39 & 8.43 & 8.04 & 10.34 & 28.09 & 6.05 \\
\hline 13.43 & 12.69 & 14.02 & 11.64 & 18.57 & 20.00 & 7.25 & 15.88 & 22.56 & 27.88 & 26.51 & 25.63 & 26.60 & 19.57 & 26.98 \\
\hline 100.00 & 100.00 & 100.00 & 100.00 & 100.00 & 100.00 & 100.00 & 100.00 & 100.00 & 100.00 & 100.00 & 100.00 & 100.00 & 100.00 & 100.00 \\
\hline 0.00 & 0.00 & 0.00 & 0.00 & 0.00 & 0.00 & 0.00 & 0.00 & 0.00 & 1.33 & 2.41 & 0.00 & 1.48 & 2.98 & 0.00 \\
\hline $20-21$ & $25-26$ & $30-31$ & $35-36$ & $40-41$ & $45-46$ & $50-51$ & $55-56$ & $60-61$ & $65-66$ & $70-71$ & $75-76$ & & & \\
\hline 74.75 & 86.07 & 76.47 & 78.86 & 76.47 & 75.63 & 81.97 & 72.41 & 69.17 & 63.89 & 65.13 & 73.48 & & & \\
\hline 10.10 & 4.10 & 8.40 & 9.76 & 5.88 & 5.88 & 5.74 & 6.03 & 8.33 & 14.81 & 6.58 & 3.79 & & & \\
\hline 15.15 & 9.84 & 15.13 & 11.38 & 17.65 & 18.49 & 12.30 & 21.55 & 22.50 & 21.30 & 28.29 & 22.73 & & & \\
\hline 100.00 & 100.00 & 100.00 & 100.00 & 100.00 & 100.00 & 100.00 & 100.00 & 100.00 & 100.00 & 100.00 & 100.00 & & & \\
\hline 1.01 & 0.00 & 0.84 & 0.81 & 0.00 & 0.84 & 0.00 & 0.86 & 0.00 & 0.00 & 0.00 & 0.00 & & & \\
\hline $60-61$ & $65-66$ & $70-71$ & $75-76$ & $79-80$ & $85-86$ & & & & & & & & & \\
\hline 71.51 & 78.57 & 77.78 & 79.37 & 66.50 & 58.70 & & & & & & & & & \\
\hline 7.53 & 0.79 & 1.85 & 1.35 & 1.78 & 7.61 & & & & & & & & & \\
\hline 20.97 & 20.63 & 20.37 & 19.28 & 31.73 & 33.70 & & & & & & & & & \\
\hline 100.00 & 100.00 & 100.00 & 100.00 & 100.00 & 100.00 & & & & & & & & & \\
\hline 0.00 & 0.00 & 0.37 & 0.00 & 0.00 & 0.00 & & & & & & & & & \\
\hline \multicolumn{15}{|l|}{$59-60$} \\
\hline \multirow{5}{*}{\multicolumn{15}{|c|}{$\begin{array}{r}67.83 \\
0.00 \\
32.17 \\
\mathbf{1 0 0 . 0 0} \\
0.00\end{array}$}} \\
\hline & & & & & & & & & & & & & & \\
\hline & & & & & & & & & & & & & & \\
\hline & & & & & & & & & & & & & & \\
\hline & & & & & & & & & & & & & & \\
\hline \multicolumn{15}{|l|}{$58-59$} \\
\hline \multirow{5}{*}{\multicolumn{15}{|c|}{$\begin{array}{r}77.52 \\
4.19 \\
18.29 \\
\mathbf{1 0 0 . 0 0} \\
0.00\end{array}$}} \\
\hline & & & & & & & & & & & & & & \\
\hline & & & & & & & & & & & & & & \\
\hline & & & & & & & & & & & & & & \\
\hline & & & & & & & & & & & & & & \\
\hline $60-61$ & $65-66$ & $68-69$ & & & & & & & & & & & & \\
\hline 75.48 & 74.55 & 77.09 & & & & & & & & & & & & \\
\hline 2.14 & 1.42 & 1.31 & & & & & & & & & & & & \\
\hline 22.38 & 24.03 & 21.60 & & & & & & & & & & & & \\
\hline 100.00 & 100.00 & 100.00 & & & & & & & & & & & & \\
\hline 1.05 & 0.47 & 0.26 & & & & & & & & & & & & \\
\hline $50-51$ & $55-56$ & $60-61$ & & & & & & & & & & & & \\
\hline 68.61 & 64.99 & 67.97 & & & & & & & & & & & & \\
\hline 0.47 & 1.34 & 1.49 & & & & & & & & & & & & \\
\hline 30.91 & 33.66 & 30.54 & & & & & & & & & & & & \\
\hline 100.00 & 100.00 & 100.00 & & & & & & & & & & & & \\
\hline 0.24 & 0.38 & 0.50 & & & & & & & & & & & & \\
\hline
\end{tabular}

\begin{tabular}{|c|c|c|c|c|c|c|c|c|c|c|c|c|c|c|}
\hline $59-60$ & $64-65$ & $69-70$ & $74-75$ & $79-80$ & & & & & & & & & & \\
\hline 15.43 & 14.78 & 20.46 & 19.80 & 27.50 & & & & & & & & & & \\
\hline 6.39 & 3.97 & 7.58 & 3.96 & 5.78 & & & & & & & & & & \\
\hline 78.18 & 81.25 & 71.97 & 76.24 & 66.72 & & & & & & & & & & \\
\hline 100.00 & 100.00 & 100.00 & 100.00 & 100.00 & & & & & & & & & & \\
\hline 0.00 & 1.71 & 0.77 & 0.00 & 0.94 & & & & & & & & & & \\
\hline \multicolumn{15}{|l|}{$55-56$} \\
\hline \multirow{5}{*}{\multicolumn{15}{|c|}{$\begin{array}{r}51.80 \\
2.85 \\
45.35 \\
\mathbf{1 0 0 . 0 0} \\
0.00\end{array}$}} \\
\hline & & & & & & & & & & & & & & \\
\hline & & & & & & & & & & & & & & \\
\hline & & & & & & & & & & & & & & \\
\hline & & & & & & & & & & & & & & \\
\hline $14-15$ & $15-16$ & $16-17$ & $18-19$ & $19-20$ & $20-21$ & $25-26$ & $30-31$ & $40-41$ & $50-51$ & $60-61$ & $70-71$ & $80-81$ & $90-91$ & $100-$ \\
\hline 33.65 & 40.58 & 37.29 & 38.57 & 71.15 & 47.83 & 56.57 & 59.81 & 63.16 & 63.93 & 60.22 & 67.78 & 71.63 & 64.06 & 72.34 \\
\hline 3.85 & 5.80 & 8.47 & 5.71 & 3.85 & 7.61 & 8.08 & 1.87 & 1.75 & 0.00 & 1.08 & 0.00 & 0.00 & 1.56 & 2.13 \\
\hline 62.50 & 53.62 & 54.24 & 55.71 & 25.00 & 44.57 & 35.35 & 38.32 & 35.09 & 36.07 & 38.71 & 32.22 & 28.37 & 34.38 & 25.53 \\
\hline 100.00 & 100.00 & 100.00 & 100.00 & 100.00 & 100.00 & 100.00 & 100.00 & 100.00 & 100.00 & 100.00 & 100.00 & 100.00 & 100.00 & 100.00 \\
\hline 0.00 & 0.00 & 0.00 & 1.43 & 0.00 & 0.00 & 0.00 & 0.00 & 0.00 & 0.00 & 0.00 & 0.00 & 0.00 & 0.00 & 0.00 \\
\hline
\end{tabular}




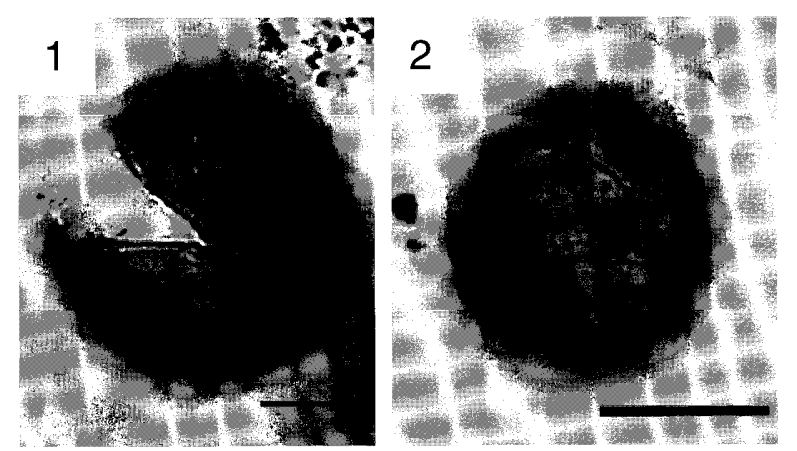

Figure 4. Reticulate cysts of two different diameters: 1 . Cyst of Gymnodinium catenatum Graham collected from Imari Bay, 2. Smaller cyst of Gymnodinium sp. collected from Imari Bay. The morphological difference is present only in cyst diameter of these similar two reticulate cysts.

smaller cysts are ornamented with fine reticulation and which possesses an epicystal archeopyle possibly inhabits West Japan.

\section{Low concentration of the cyst of Gymnodinium cate- natum}

Matsuoka and Fukuyo (1994) suggested that the cyst concentration of $G$. catenatum in sediments is very low in comparison with other red-tide-causing dinoflagellate species. McMinn et al. (1997) illustrated the vertical profile of the abundance of $G$. catenatum cysts in core sediments collected from Tasmania, Australia. In these cores, the occurrence of the cyst was always less than $2 \%$ of the total cyst population. Similarly, the relative frequency of $G$. catenatum cysts was always very low (less than $8 \%$ in the case of the highest abundance) during this study, in comparison to other cysts of autotrophic species such as Spiniferites bulloideus and Protoceratium reticulatum. Gymnodinium catenatum is a chain-forming species and easily forms a colony consisting of more than eight cells. This can lead to a large number of vegetative cells in surface waters. Although the cyst-forming process of this species is not yet fully understood, the following interpretation is possible: during the cyst-forming process, a single cell separating from a chain is provided in sexual reproduction. In culture conditions, cells forming a chain can survive only for a while after separating, however, they do not act as gametes in sexual reproduction. During a bloom, most of the cells of $G$. catenatum make chains and only a few single cells become gametes. Therefore, cyst formation might be very low in spite of a large population of motile cells as a result of asexual reproduction.

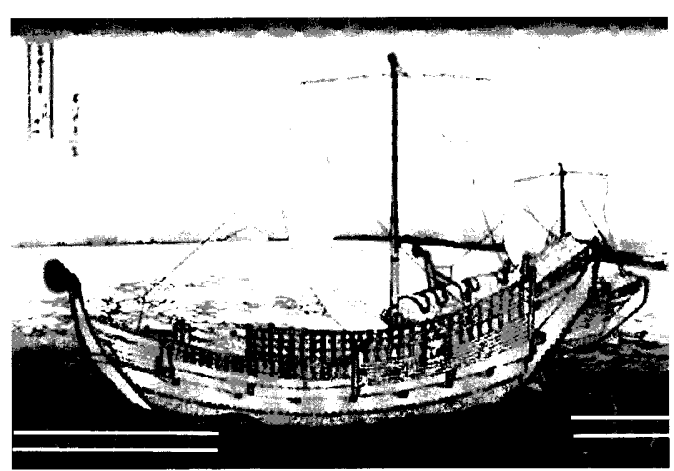

Figure 5. Typical Japanese ship in the Edo period. Most of the oldest occurrence of Gymnodinium catenatum in core samples provided for this study was recorded in this period. The original illustration from a Japanese stamp.

\section{Gymnodinium catenatum as a natural species in Japan}

In Omura Bay, the earliest occurrence of this species was recorded in sediment dated to ca. 1700 A.D. In Nagasaki Bay, G. catenatum appeared around ca. 1870 A.D. In Imari Bay, the earliest occurrence of $G$. catenatum was dated back to ca. 1825 A.D. The earliest recorded occurrence of this species dates back to the Edo period in Japan. At that time, the Japanese government followed a policy of national isolation, and the old Japanese ships (Figure 5) were made of wood and did not employ ballast water tanks. There is no possibility that Japanese $G$. catenatum could have been artificially introduced within ballast waters from other areas. This fact strongly suggests that the occurrence of $G$. catenatum is natural in Japan.

More than ten years before, the geographical distribution of G. catenatum in Japanese coastal waters was reported by Matsuoka and Fukuyo (1994). Since then, the appearance of this species has been investigated (Red Tide Division of Nansei National Fisheries Research Institute, 1998). This data shows that the areas where G. catenatum now appears increased during the 1990's, particularly in West Japan. Two possibilities for this apparent increase can be considered; its distribution really is expanding; or there are more records of this species, even of small numbers of cells, because increased interest in harmful algae has drawn more researchers into looking for its presence.

Our results indicate that the latter is correct. The increasing number of reports of $G$. catenatum in Japanese waters is not due to artificial spread of its distribution area, but rather to increased, intensive monitoring for harmful algae. Increased occurrences of this species are probably caused by environmental 
change in coastal areas, namely the progress of artificial eutrophication, change of current systems after coastal construction, and change of the coastal ecosystem, thereby creating a more favorable environment for $G$. catenatum. The reason for the recent increase of $G$. catenatum in Japanese coastal waters is different from that in Australia where this species might have been introduced from other regions by ballast waters (Hallegraeff, 1992; McMinn et al., 1992).

\section{Acknowledgements}

We thank H.-J. Cho for her kind help in the collection and analysis of samples, and also to Lind B. Joyce, Vera Pospelova and Hiroshi Kurita for their critical reading of the manuscript and constructive suggestions. This work was partially supported by a Grant-in-Aid JSPS (Grant Number 13854006).

\section{References}

Anderson, D. M., Jacobson, D., Bravo, I. and Wrenn, J.H., 1988: The unique, microreticulate cyst of the naked dinoflagellate, Gymnodinium catenatum Graham. Journal of Phycology, vol. 24, p. 255-262.

Bolch, C. J. S., Negri, A. P. and Hallegraeff, G. M., 1999: Gymnodinium microreticulatum sp. nov. (Dinophyceae): a naked, microreticulate cyst-producing dinoflagellate, distinct from Gymnodinium catenatum and Gymnodinium nolleri. Phycologia, vol. 38, no. 4, p. 301-313.

Bolch, C.J.S. and Reynolds, M. J., 2002: Species resolution and global distribution of microreticulate dinoflagellate cysts. Journal of Plankton Research, vol. 24, p. 565-578.

Dale, B., Madsen, K., Nordberg, K. and Thorsen, T. A., 1993: Evidence for prehistoric and historic "blooms" of the toxic dinoflagellate Gymnodinium catenatum in the KattegatSkagerrak region of Scandinavia. In, Smayda, T.J. and Shimizu, Y. eds., Toxic Phytoplankton Blooms in the Sea, p. 47-52. Elsevier Science Publishers, Amsterdam.

Ellegaard, M. and Moestrup, Ø., 1999: Fine structure of the flagellar apparatus and morphological details of Gymnodinium nolleri sp. nov. (Dinophyceae), an unarmored dinoflagellate producing a microreticulate cyst. Phycologia, vol. 38 , no. 4 , p. 289-300.

Furio, E. F., Fukuyo, Y., Matsuoka, K. and Gonzales, G. L., 1996: The vertical distribution of resting cysts of PSPproducing dinoflagellate Pyrodinium bahamense var. compressum in Manila Bay, Philippines. In, Yasumoto, T., Oshima, Y. and Fukuyo, Y. eds., Harmful and Toxic Algal Blooms, p. 185-188, International Oceanographic Commission of UNESCO.

Hallegraeff, G. M., 1992: Toxic dinoflagellates necessitate restrictions on Tasmanian shellfish stock movements. Tasmania Aquaculture Society Newsletter, July, p. 4.

Hallegraeff, G. M., 1993: A review of harmful algal blooms and their apparent global increase. Phycologia, vol. 32, p. $79-99$.
Hodgkiss, I. J. and Yang, Z.-b., 2001: New and dominant species from Sam Xing Wang, Sai Kung during the 1998 massive fish killing red tide in Hong Kong. In, Hallegraeff, G. M., Blackburn, S. I., Bolch, C.J. and Lewis, R. J. eds., Harmful Algal Blooms 2000, p. 62-65, International Oceanographic Commission of UNESCO.

Ikeda, T., Matsuno, S., Sato, S., Ogata, T., Kodama, M., Fukuyo, Y. and Takayama, H., 1989: First report on paralytic shellfish poisoning caused by Gymnodinium catenatum Graham (Dinophyceae) in Japan. In, Okaichi, T., Anderson, D. M. and Nemoto, T. eds., Red Tide: Biology, Environmental Science and Toxicology, p. 411-414. Elsevier, New York.

Jeter, H.W., 2000: Determining the ages of recent sediments using measurements of trace radioactivity. Terra et Aqua, no. 78 , p. $21-28$.

Kim, H.-S. and Matsuoka, K., 1998: Process of eutrophication estimated by dinoflagellate cyst assemblages in Omura bay, Kyushu, West Japan. Bulletin of Plankton Society of Japan, no. 45, p. 133-147. (in Japanese)

Matsuoka, K. and Fukuyo, Y., 1994: Geographical distribution of the toxic dinoflagellate Gymnodinium catenatum Graham in Japanese coastal waters. Botanica Marina, vol. 37, p. $495-503$.

Matsuoka, K. and Fukuyo, Y., 2000: Technical Guide for Modern Dinoflagellate Cyst Study, v+29p. WEATPACHAB/WEATPAC/IOC, Japan Society of the Promotion of Science, Tokyo.

Matsuoka, K., Fukuyo, Y. and Anderson, D. M., 1989: Methods for modern dinoflagellate cyst studies. In, Okaichi, T., Anderson, D. M. and Nemoto, T. eds., Red Tide: Biology, Environmental Science and Toxicology, p. 461-479. Elsevier, New York.

Matsuoka, K. and Kim, H.-S., 1999: Process of eutrophication in enclosed seas recorded in dinoflagellate cyst assemblage and sediments - the case in Nagasaki Bay, west Japan-. Fossils (Palaeontological Society of Japan), no. 66, p. 115. (in Japanese)

McMinn, A., Hallegraeff, G. M., Thomson, P., Jekison, A. V. and Heijinis, H., 1997: Cyst and radionucleotide evidence for the recent introduction of the toxic dinoflagellate $G y m$ nodinium catenatum into Tasmanian waters. Marine Ecology Progress Series, vol. 161, p. 167-172.

McMinn, A., Hallegraeff, G. M., Roberts, J., Smith, J., Lovell, A., Jenkinson, A. and Heijinis, H., 2001: Recent introduction of Gymnodinium catenatum to Port Lincoln, South Australia. In, Hallegraeff, G. M., Blackburn, S. I., Bolch, C. J. and Lewis, R. J. eds., Harmful Algal Blooms 2000, p. 477-480, International Oceanographic Commission of UNESCO.

Nanba, K., Iida, T., Fukuyo, Y. and Matsuoka, K., 1998: A handy piston core sampler for sediments in shallow water. Fisheries Science, vol. 64, p. 985-986.

Red Tide Division in Nansei National Fisheries Research Institute, 1998: Frequent occurrences of paralytic shellfish poisoning caused by Gymnodinium catenatum in West Japan. Aqua Culture Magazine, vol. 35, no. 5, p. 92-93. (in Japanese)

Viques, R. and Hargraves, P.E., 1995: Annual cycle of potentially harmful dinoflagellates in the Golfo de Nicoya, Costa Rica. Bulletin of Marine Science, vol. 57, p. 467-475. 